\title{
Towards understanding of policy transfer and policy learning in adult education in the context of United Kingdom
}

Research in Comparative \& International Education 202I, Vol. 0(0) I-2I (c) The Author(s) 2021 (c) (1)

Article reuse guidelines: sagepub.com/journals-permissions DOI: 10.1 I77/I74549992। I06/236 journals.sagepub.com/home/rci

๑SAGE

\section{Natasha Kersh}

UCL Institute of Education, London, UK

\section{Andrea Laczik}

Edge Foundation, London, UK

\begin{abstract}
Over the past decade, adult education and Vocational Education and Training (VET) in the UK context have been strongly affected by the implications of unstable political, social and economic situations, specifically in relation to social and economic inclusion of vulnerable young adults. This paper argues, that the development of policy transfer and policy learning in adult education has been characterised by its multidimensional nature and has been influenced by the implications of contemporary global challenges, country-specific priorities and the European agenda on inclusion. The notion of policy learning in adult education highlights the complex interdependencies between policies and practices. We will endeavour to consider how the complex interplays between countryspecific priorities, global discourses and the European agenda on active citizenship (AC) contribute to national policies and practices for social inclusion of young adults in the UK context. Selected case studies will demonstrate the ways this policy agenda transfers into specific programmes for vulnerable young adults.
\end{abstract}

\section{Keywords}

active citizenship, adult education, social inclusion, young adults, policy learning

\section{Introduction}

The paper considers the complex interplay between policy and practice in relation to adult education and social inclusion in the context of UK, specifically considering the role and influence of international discourses on the landscape of adult education. The role of international discourses (both European and global) in shaping national policies and practices in adult education has been increasingly recognised in policy documents and academic literature (see Biesta, 2006; Holford et al., 2008).

\section{Corresponding author:}

Natasha Kersh, UCL Institute of Education, 20 Bedford Way, London WCIH OAL, UK.

Email: n.kersh@ucl.ac.uk 
Over the past decade, adult education in the UK context, has been strongly affected by the implications of contemporary global challenges, such as the implications of the financial crisis of 2008 , unemployment as well as migration and the influx of refugees from Europe and other parts of the world. More recently, political and social trends, such as migration, the rise of far-right powers in some European countries and results of the Brexit referendum in the UK in 2016, have affected both European and national contexts, contributing to the changing perceptions of social inclusion and citizenship, as well as to tensions and often hostility between 'local' and 'migrant' populations (Kersh et al., 2021). Policies and practices that aim to promote social and economic inclusion have become important items of the European Lifelong Learning agenda. Specifically, the concept of Active Citizenship (AC) has been increasingly promoted as a means to contribute to social and economic inclusion through lifelong learning and social participation (Field and Schemmann, 2017). Both the impact of some global challenges and European AC policies have, in many ways, shaped the national policy and practice responses in relation to inclusion strategies through adult education. In this paper, we endeavour to answer the question: how does the interplay between country-specific priorities, global discourses and the European agenda on AC contribute to and shape national policies and practices for social inclusion of vulnerable young adults in the UK context? The ways educational policies are developed are complex, and there is some overlap in the literature, between some key processes of policy development such as policy borrowing (e.g. Phillips and Ochs, 2003), policy learning (e.g. Raffe, 2011a), policy transfer (e.g. Crossley, 2019) and policy referencing (e.g. Forestier et al., 2016). In this paper, we consider the notion of transferring or borrowing policy in a broad sense, embracing the concept of policy learning (Raffe, 2011a, 2011b; Raffe and Spours, 2007) to take into account the influence of globalisation (Crossley, 2008) and the way the political and social trends across influence or translate into the UK national policies and practices on social inclusion, specifically in relation to vulnerable young adults. In doing so, we are drawing on Raffe and Spour's framework (Raffe and Spours, 2007) that proposes a three-dimensional approach towards considering the notion of policy learning. That is, (1) 'experiential learning' or learning from past experience, (2) learning from other countries and (3) learning from local innovations and experiments. As Raffe makes a point in his later work (Raffe, 2011b), the distinction between the concepts of policy borrowing and policy learning, is that policy borrowing involves searching the international experience for transferable 'best practice' while policy learning uses this experience for a wider range of purposes, including understanding one's own system better, identifying common trends and pressures that affect all systems, and identifying issues raised by some strategies. As Burdett and O'Donnell (2016) further suggest, the difference between policy learning, policy referencing and policy borrowing is that policy learning imply that no actual policy or practice is explicitly transferred, but rather this process contributes to informing local solutions where local contexts are considered. Within the paper, the consideration of some influential global trends and discourses as well as national and European responses will contribute to exploring the dimension of learning from past experience, common global discourse and major international trends. In addition, learning through innovations and experiments, as part of the policy learning process, will be illustrated through two empirical case studies.

The paper will first introduce the context and methodology of the research: we will draw on both the desk study and empirical findings of the EduMAP Horizon 2020 research project $^{1}$ dealing with

1. This paper draws on findings of the research project Adult Education as a Means to Active Participatory Citizenship (EduMAP). The project was funded by the European Union under the European Union's Horizon 2020 Research and Innovation Programme (H2020-YOUNG-2014-2015/H2020-YOUNG-SOCIETY-2015), Grant Agreement number 693388. 
issues of adult education and young adults at risk of social exclusion. The paper will subsequently continue with discussion of some global trends and discourses, and their impact on adult education needs and challenges. The paper will further consider some important national responses such as policies and strategies to facilitate the inclusion, engagement and employability of young adults, often driven by learning from past experiences and policies, both national and international (Raffe and Spours, 2007). Embedding these policies and agendas into specific adult education contexts will be illustrated through two respective cases from England and Scotland. The consideration of these two cases will further demonstrate that the interplay between country-specific priorities, global discourses and the European agenda has contributed to some common patterns and approaches to inclusion of vulnerable young adults. In this paper, we argue that the overall policy directions and policy learning have been influenced and shaped by both the global discourses and national priorities. However, translating these policies into specific adult education settings is highly contextualised, driven by the needs of specific target groups, and often involves the process of local adaptations (Steiner-Khamsi, 2014) as well as learning through local innovations and experiences (Raffe and Spours, 2007). The paper will conclude with a summary and discussion on the main findings concerning the interplay between policy and practice, suggesting some directions for future research.

\section{Methodology}

The paper draws on both theoretical perspectives in relation to policy developments in adult education and empirical findings from the Horizon 2020 project 'Adult Education as a Means to Active Participatory Citizenship' (EduMAP). In the course of the project, particular attention was paid to educational policies and practices needed to foster AC among young people facing different types of vulnerabilities. In order to address the complex issues raised by this research, both desk and empirical research were undertaken. This covered undertaking a review of the relevant literature, including research publications, policy papers and materials related to various educational initiatives to facilitate the inclusion of young adults in vulnerable positions. The review of the relevant literature and policy papers has contributed to the consideration of the first part of our research question, in relation to discourses and trends that influence inclusion policies. Specific practices, and the translation of these policies in particular adult education settings have been explored through our empirical data: interviews and focus groups with key stakeholders. Overall, empirical fieldwork involved researching some 40 adult education programmes across 20 countries: Austria, Cyprus, Denmark, Estonia, Finland, France, Germany, Greece, Hungary, Ireland, Italy, Latvia, Malta, Netherlands, Portugal, Romania, Spain, Sweden, Turkey and the UK. Individual and focus group interviews were conducted with some 814 participants in total: 482 young learners and 332 professionals (teachers and other practitioners and policy makers). In selecting the types of educational programmes and respondents, the sampling approach was employed to ensure both the diversity (e.g. in terms of different types of programmes and different cohorts of young adults) and focus on AC.

In this paper, we will draw on our sample drawn from UK-based cases, based on interviews and focus groups with some 107 respondents $^{2}$. We have carried out research across 4 adult education programmes in Scotland and England, through interviews (individual and focus groups) with learners, educational practitioners and policy informants. Programmes ranged from: mentoring for

2. We wish to acknowledge the invaluable field work and data analysis contributions of our co-researchers Dr Nathalie Huegler, Dr Helen Lawson, and Dr Mai Abu Moghli. 
care experienced young people (Case 1); vocational programme in a small community college (Case 2); ESOL (English for Speakers of Other Languages programme (Case 3) and 'gateway' programme for unemployed young adults (Case 4). In this paper, we will specifically discuss and provide illustrations from Case 1 and Case 2; however, our conclusions and discussion will draw on our overall findings supported by all case studies undertaken within this project.

\section{Policy developments and the influence of global trends and challenges: Adult education, social inclusion and $A C$}

Understanding how national policies and practices on inclusion are shaped and developed has been a focus of interest in many studies (e.g. Evans and Niemeyer, 2004; Field and Schemmann, 2017; Holford et al., 2008). Current and recent social challenges, including the consequences of the 2008 economic crisis and the influx of refugees and migrants across Europe and beyond, have indicated the need to address a wide range of issues, such as enhancing the employability skills of disengaged and disadvantaged young adults and facilitating social and economic inclusion of migrants. (e.g. GRALE, 2016, 2019; Jarvis, 2012; Saar et al., 2013). Policies that aim to tackle social exclusion have become an important item of the European Life Long Learning (LLL) agenda, and the development and implementation of these policies at national and European levels have involved active policy learning (Raffe and Spours, 2007) through both learning from the instances of past policy and practice and learning from other countries, as well as global experiences and trends The consideration learning from policies and practices to address the needs of vulnerable young adults indicates some common trends in their development and implementation across Europe and beyond (Kersh et al., 2021). The reason for this, as noted by Biesta (2006:169), is that that 'governments and policy makers are responding to the same challenges, most notably the globalisation of the economy and the need to remain competitive in the global marketplace, increasing levels of migration and mobility, and the globalisation of information, communication and the entertainment industry'. Biesta (2006) further suggests that the strong convergence in policy and practice can be partly attributed to the discourses and policy frameworks generated by trans- or supra-national organisations such as the Organisation for Economic Cooperation and Development (OECD) and the European Union. Milana and Holford (2014) similarly note that the EU, and especially the European Commission over the last decade, has given a particular profile to adult education and adult learning, and some influential documents, such as EU policy statements: Adult Learning: It is Never Too Late to Learn (Commission of the European Communities, 2006) and Action Plan on Adult Learning: It is Always a Good Time to Learn (Commission of the European Communities, 2007) have largely stimulated policy direction in adult learning across European countries. Therefore, as also concluded by Breyer (2018: 152), it is no longer the nation-state alone that is regulating policy, this is a consequence of globalisation and the role of international organisations such as UNESCO and EU regarding processes of policy-making is increasing. This suggests that the development of policies and practices to facilitate the social inclusion of young adults have been influenced and shaped by the changing contexts and discourses across Europe, which have been becoming increasingly diverse, multicultural and multilingual, resulting in a range of social issues and challenges such as tensions and often hostility between local and newcomers (i.e. refugees and migrant) populations. Trends, such as migration, the rise of far-right powers in some European countries, results of the Brexit referendum in the UK in 2016 and, more recently, the Covid-19 pandemic ${ }^{3}$ have affected

3. This paper primarily focuses on pre-covid research, undertaken in 2016-2019. 
both European and national contexts, contributing to the changing perceptions and opportunities for social inclusion and AC. Over the past decade, the influx of refugees and migrants across Europe has become one of the most significant social challenges in many European countries, and finding approaches for integration and inclusion has been identified as one of the most pressing tasks to be addressed at local, regional and national policy levels (Kersh and Huegler, 2018). Policy developments in adult education have been influenced by two powerful discourses which have played a prominent role in setting the vision of adult education requirements in contemporary society (Kersh et al., 2021). Neo-liberal trends, underpinning the economic value of education, have contributed to the corresponding discourse, particularly emphasising the notion of learning for earning with a focus on employability (Evans, 2009). Migration was another key trend, and this has emphasised the importance of social and civic integration, such as developing national language skills, embracing national culture and values, and becoming a loyal citizen. The implications for adult education have involved developing new programs and adapting existing practices to emphasize the provision of skills that would enable adults to adapt to their new environments and overcome political, economic or social challenges through social and economic participation.

The effects of the COVID-19 crisis across Europe and beyond have had a profound impact on both policies and practices in relation to adult education. The pandemic has further affected those who have already been at risk of disadvantage and vulnerability, and as noted by Waller et al. (2020) with this crisis occurring just over a decade since the global recession that began with the international banking crashes of 2008, the virus has further exacerbated the pre-existing social and economic inequalities, further affecting access and participation to lifelong learning and adult education (James and Thériault, 2020; Waller et al., 2020).

The consideration of both pre-Covid and post-Covid challenges, opportunities and priorities for adult education indicates a strong focus on facilitating employability and inclusion through adult learning. The overlap between economic and social inclusion has been evident in both national and global adult education priorities, policies and practices (Kersh et al., 2021). In this respect, the concept of AC has been often employed to highlight the interlinks between social, economic and political inclusion and participation.

The concept of AC has emerged as a political goal in many countries around the world. Within the official European policy, the idea of AC first emerged in the context of the Lisbon European Council in 2000. The strategic goal set for the European Community was to become the most competitive and dynamic knowledge-based economy in the world with more and better jobs and greater social cohesion (Lisbon European Council, 2000). In the communication Making a European Area of Lifelong Learning a Reality, the European Commission promoted three major pillars, one of which was learning for AC (see Commission of the European Communities, 2001). More recently, the role of AC in addressing economic, social and environmental disparities has been emphasised by the Europe 2020 Strategy, specifically bringing attention to the role of AC in facilitating social cohesion. Furthermore, the 'Resolution on a Renewed Framework for European Cooperation in the Youth Field' (2010-2018) has specifically stressed the role of adult learning that provides a means of up-skilling or reskilling those affected by unemployment and contributes to social inclusion, AC and personal development. (Council of the European Union, 2011: 1). Overall, over the past twenty years, the debate on AC has been related to a widespread concern that adults, may be passive rather than active members of their communities, and, may experience various barriers that hamper their participation and engagement with AC. (Brooks and Holford, 2009; Henn et al., 2005; Vromen, 2003). The interpretation of the notion of AC is that a person is actively involved in participation in activities that support their community. One perspective is to consider this at the level of the nation-state, but the notion of 'community' may also relate to the local level, 
or, on the contrary, the wider level, for example, European or global communities. In this paper, the concept of Active (participatory) Citizenship, has been used for better understanding of common policy approaches to inclusion and participation of vulnerable young adults. The specific dimensions of AC, socio-economic, socio-cultural and politico-legal, conceptualised elsewhere (see Kersh et al., 2021), will provide the conceptual lens to explore the implementation of polices within more specific contexts of adult education programmes.

\section{Policy development and national contexts (UK): Policy learning from national and international discourses}

The context of adult education, relevant to the social inclusion of young adults, has been influenced by political, social and economic discourses ${ }^{4}$ as well as historical and contemporary policy developments in the UK. In the UK context, the role of different forms of adult education in promoting both employability and engagement for young people, including those suffering from different types of disadvantages, has long been recognised in both policy and research, and learning and taking into account past national policy experiences have contributed to the current policy developments. In addition, the employability and economic competitiveness agenda has been in many ways influenced by the corresponding European and global socio-economic discourses. Over the past decade raising the skills level of the adult population as a way of increasing competitiveness in the global economic has been an important political objective across European countries (Kersh and Huegler, 2018). As an implication of these trends, contemporary national education policies have largely exemplified extensive common patterns and policy learning, and for adults they have generally underpinned the socio-economic dimensions, that is, a close alignment between education and training and paid employment (Boeren and Holford 2016; Evans, 2009; Kersh and Huegler, 2018).

Concomitantly, in the UK, the landscape of adult education has been influenced by a concern for socio-economic inclusion, particularly through facilitating employability of those who are at risk of economic exclusion, for example, unemployed and/or in need of social benefits. These economic objectives have driven a number of prominent integration schemes and approaches, where the development of young people's employability skills has been emphasized as a precondition of their social inclusion. In recent years, policy developments in particular, in adult education, have been strongly underpinned by neo-liberalism, addressing global competitiveness, the market economy, and its skill demands. A gradual shift from the perspective of adult education as liberal education to its interpretation as a means of enhancing the economic competitiveness and employability has been influenced by both global trends and country-specific developments (Kersh and Huegler, 2018; Volles, 2014). It is worth noting, that until the 1980s, the term adult education was closely associated with liberal education. The gradual transition in the role of adult education has been seen from the 1970s, when the purpose of liberal adult education was criticised and questioned (Holford and Welikala, 2013). These developments have been influenced by a range of factors. Both the global social-economic discourses and internal factors such as global migration, the rise in the unemployment rates and the increase in the number of early school leavers have contributed significantly to the prevalence of the socio-economic objectives. Such refocussing of adult education has been further facilitated by an emerging European Lifelong Learning (LLL) agenda on learning, employability and inclusion. The Faure report (Faure et al., 1972) 'Learning to be: the world of

4. For more detailed discussion and explanation about the notion of political, social and economic discourses, please see Kersh et al. (2021). 
education today and tomorrow' was an important milestone, to promote a new vision of LLL, highlighting the significance of learning through the lifespan as individuals face a number of challenges in a changing world and equipping adults with employability skills was perceived as an important dimension of LLL. Other influential EU policy papers have similarly underpinned the role of LLL in strengthening European competitiveness and economic growth (e.g. Commission of the European Communities, 2000; Council of the European Union, 2016; European Commission, 2016), and these policy trends have been further supported by other major international organisations, such as OECD, UNESCO and the World Bank (Biesta, 2006).

Some prominent policy developments addressing employability and inclusion of vulnerable young adults have been related to the broad notion of NEETs (Not in Education, Employment or Training). In the UK the acronym 'NEET' has received its prominence from the 1990s onwards, to indicate those excluded from work and learning. Addressing the needs of NEETs has contributed to the development of some influential policy paradigms, which aimed to design, implement and sustain intervention programmes targeted to these groups. In response to these agendas, many educational programmes and policy initiatives in the UK have been implemented to meet the needs of these target groups, specially through facilitating their engagement in further and adult education or employment. In the UK, much of adult education happens in further and adult education colleges. The number of adult learners has been declining since 2005 for a number of reasons, such as reduced funding and increased complexity in funding rules. In 2011, a prominent policy document, the Wolf review of vocational education in England (for 14-19 year olds), has brought attention to various setbacks of VET, and proposed a focus on core skills in English language and Maths, specifically calling for the development of effective programmes with 'genuine labour market value and credibility' (Wolf, 2011: 22). More recently, the 'Skills for Jobs: Lifelong Learning for Opportunities and Growth' White Paper (Department for Education, 2021) has brought attention to addressing the issues of lifelong learning and skills development, through initiatives such as Lifelong Loan Entitlement, reforming accountability and funding systems as well as increasing employer involvement in skills courses and better tailoring provision to local needs. In addition, the paper has emphasized the importance of recognizing the role of colleges in boosting productivity, strengthening communities and supporting individuals (Association of Colleges, 2021).

Considering these developments over the past decade, it is worth highlighting that from 2010 onwards, under the Conservative-led governments the policy development have been largely shifting even more to neo-liberalism with a stronger emphasis on individual responsibility for skills development and employability within lifelong learning. These trends have also been characterised by reduced state intervention and public spending. The perception of social inclusion and AC, is therefore, about individuals taking a more active and independent role in shaping own life chances. The Integrated Communities Strategy Green Paper (HM Government, 2018) has stressed the concept of shared responsibility, stating that

\footnotetext{
'integration is a shared responsibility and is a two-way process between migrants and their local communities. [...] people who come to live in this country will strive to integrate must be coupled with providing them with the opportunities, expectations and the environment to enable them to do that successfully, and Proficiency in English is vital for migrants to integrate within their local communities. It is key to them taking up employment and taking an active role in community life and means they can support their children and communicate with people outside their immediate family' (HM Government, 2018: 20-21).
} 
These trends have been supported, and in some ways, shaped by global and European policy developments. The strong interdependency between civic values, learning, employment and adult education has been increasingly recognised both in Europe and beyond. A Resolution adopted by the Council on a renewed European Agenda for Adult Learning (Council of the European Union, 2011) brings attention to the importance of increasing adult participation in education, to acquire employability and AC skills. A subsequent policy document (Council's Recommendations for EU Member states), stressed that education is critical for preparing immigrants, and particularly their descendants, to become more successful and more active participants in society (The Council of The European Union, 2016). In the wider global context, The GRALE $(2016,2019)$ reports have similarly placed a specific emphasis on the role of adult education for civic and citizenship skills, particularly observing that there is strong evidence that adult education can help citizens to become more active and resourceful members of their communities, specifically through helping individuals improve their social and employability skills.

EduMap's cases studies demonstrate the ways the policy agenda on AC and inclusion translates into specific adult education programmes for vulnerable young adults. The cross-national research, undertaken across some 40 adult education programme, has strongly suggested that the configurations of social, economic and political dimensions of $\mathrm{AC}$, have been underpinning these programme's goals and outcomes, either implicitly or explicitly. The findings suggest that the conceptual understanding of AC sees the empowerment of young adults to become active citizens as being accomplished first and foremost by helping them access employment and financial independence. All adult education and VET-related cases to a certain degree have this vision and also many European or national funding schemes are driving providers towards focussing foremost on employability competences. (Schmidt-Behlau, 2019). The UK cases (adult education programmes for young adults) have demonstrated some common trends in response to the political context of post-16 adult education. Overall, EduMap findings (Kersh et al., 2021) have indicated that the dimensions of AC (socio-economic, socio-cultural and politico-legal) have largely underpinned adult education programmes, aiming to facilitate social inclusion.

\section{Active citizenship and policy and practice developments: Translating policy into practice and learning from local innovations and experiments}

The key priorities of the European Active Citizenship agenda have in many ways underpinned approaches to adult education policies and strategies in relation to inclusion. The interplay between responding to the European agenda and addressing national challenges (such as unemployment and integration of migrants) have contributed to the development of adult education programmes to engage and re-engage young adults who are considered to be disengaged and vulnerable (e.g. NEETs, migrants, early school leavers and care experienced young adults). Engaging vulnerable young people through adult education has been strongly related to addressing the specific needs and requirements that would facilitate their participation in the social, economic and civic/political life in their country contexts. In these perspective, adult education programmes are equipping individuals with socio-cultural skills (i.e. the development of social competences and social capital), socio-economic dimension that relates to employment (i.e. developing employability skills) and politico-legal skills that encourage civic and political participation e.g running for boards and neighbourhood activities. (Kersh et al., 2021).

Recent developments in national policies on AC, have increasingly demonstrated its role and interpretation as a means to facilitate both economic and social inclusion. During the past two decades there have been a number of highly significant events at global, national and local levels 
which have generated an educational response, with citizenship education often being regarded as the key vehicle to bring about the desired change in attitudes and behaviour. The 2019 Report of the Centenary Commission (2019), which traced the development of national priorities from 19192019 specifically stressed the role of adult learning in fostering citizenship and inclusion through 'facilitating citizens - of all backgrounds, identities and perspectives' enabling them to contribute to constructive and critical democratic discussion. This way, as argued in the report, 'adult learning can strengthen citizenship, and support communities and organisations in addressing the great issues of our time' (Report of the Centenary Commission, 2019: 24). Thus, the aims of citizenship education in the UK (as well as many other European countries) have shifted from a focus on the rights and duties of the active citizen (e.g. voting), to an explicit requirement for citizenship to tackle issues of diversity and social cohesion. As a result, different programmes of adult education have been employed as a means to engage those who are at risk of becoming disengaged or even radicalised.

The promotion of active participatory citizenship of young people, both directly and indirectly, is an area where many adult education programs overlap. Research undertaken as part of the EduMAP project (see Kersh et al., 2021) supported the view that the development of social, political and economic skills can take place through different types of adult education and LLL. Although some programmes are specifically focused on citizenship (e.g. programs for migrants), often 'citizenship' is not used explicitly and/or may be embedded. Adult education programs and initiatives across all countries have been seen as related to social, political or economic dimensions of AC. The two UKbased cases studies, considered below, illustrate how policies translate into specific practices and approaches. The first case, considered below, is an ESOL programme for adults in England. ESOL, is a government-funded nationwide programme, which has been perceived as a tool for the social integration of adults through equipping them with language and social skills, teaching British values and contributing to AC. In recent years, the current political, economic and social changes and challenges have brought about widespread recognition of the importance of ESOL provision, as a tool for both social and economic inclusion of adults.

The second case focusses on a programme in Scotland, which aiming to improve the life chances of care experienced young people who, as research indicates, are particularly at high risk of social exclusion and poor outcomes especially in relation to education, employment, mental health. In addition, young people leaving care who are 'not in education, training or employment' (NEET) at the age of 19 being more than twice that of the general population (HM Government, 2013). The case is contextualised in wider policies which regulate support structured for this target group (e.g. Children Leaving Care Act 2000 (UK Government, 2000) and Children and Young Persons Act, 2008 (UK Government, 2008).

\section{Policy learning through embedding national strategies into specific adult education contexts: ESOL programme example}

As discussed above, a significant policy trend has been associated with widespread concerns about social and economic exclusion and segregation of migrants and refugees with limited knowledge of English language. This concern has influenced a number of policies and approaches aiming to facilitate social inclusion and the integration of those who are being held back by the lack of English language proficiency. An influential government commissioned integration review (Casey, 2016) has found that the problems of social exclusion still persist, specifically for ethnic minority groups, and that English language is 'a common denominator and a strong enabler of integration [...] and the range of socio-economic exclusion suffered by some groups must be given greater attention' (Casey, 2016: 14). The Integrated Communities Strategy Green Paper (2018) echoes these findings, 
and further makes a point that deficiencies in English language skills limit an individual's employment opportunities, their ability to mix, their civic participation and their access to services, hindering independence, confidence and self-determination.

The ESOL national programme has an explicit focus on young adults (19+) whose first language is not English and who need English to communicate in daily life, either for work or social purposes. It has been observed, that ESOL learners are very diverse, including both educated professionals and individuals with no experience of education, and some of them may be illiterate and are not literate in their first language (Foster and Bolton, 2018: 5).

The role of ESOL in addressing and responding to both the global challenges of and national priorities has been contextualised and shaped by relevant policy developments. The government commissioned Casey review (Casey, 2016) highlights the role of ESOL, in facilitating adults' life chances, noting that there is a clear link between the level of English spoken and the level of qualifications attained, and between levels of English and employment rates and labour market capabilities. Furthermore, the 2019 Report of the Centenary Commission (2019), specially stressed that 'poor language skills damage citizenship and create isolation and a fragmented society, leading to a loss of equality and social exclusion' (16.) ESOL case (Case 3) researched within the EduMap project presents an example of ESOL provision in an Adult Education College in South London (England, UK). The college is a registered charity, a non-profit organization and ESOL provision at the college is a long-established development that has been delivered and facilitated through the collaborative work and commitment of the ESOL department staff. The learners targeted by the programme are perceived as those at risk of social and economic exclusion. The implementation of the policy agenda on AC and inclusion into ESOL provision in the college, been facilitated through continuous learning from local innovations and experience. With a specific focus on the three dimensions of AC: socio-cultural, socio-economic and politico-legal.

\section{Developing employability through enhancing language and communication skills: Socio-cultural and socio-economic dimensions}

ESOL provision in the UK reflects the history of UK immigration, and illustrates how its policies and practices have been shaped by both global developments and national country-specific agendas. The Until 2001, ESOL provision was informal in nature. In 2001, the then Labour government initiated the national Skills for Life strategy: the national strategy for improving adult literacy and numeracy skills. The strategy has introduced national standards, a national core curriculum for adult literacy and numeracy qualifications. This strategy, had a twofold aim: (1) to enhance the life chance of adults by boosting their employability through equipping them with language and communication skills, and (2) to facilitate the social integration of newcomers (such as refugees and migrants). The response at local policy levels has been to make the ESOL programme more employability oriented, as 'entering employment makes young adults more confident and socially engaged' (Toiviainen et al, 2019: 57). The findings from the ESOL case, researched as part of the EduMap study, have illustrated the ways the employability agenda has been contextualised in a specific case, involving joint efforts of various stakeholders.

Equipping learners with socio-economic skills, that is, skills that would enable them to succeed in the job market, has been considered an important element of this programme. Socio-economic skills are being embedded into the programmes, and this is reflected in both classroom activities and wider support services in the college (e.g. career guidance service). The philosophy that underpins ESOL provision in the college is based on a strong conviction that ESOL teaching and learning should 'move the learners on', facilitate their confidence and provide a sound foundation for their 
further learning and professional careers One of the practitioners notes that the college adopts a student-oriented approach, taking into account individual learning needs as well as opportunities for career progression and development:

[...] not only do they [the college] have a community learning department but they also have an additional learning support department, so for people who have special additional learning needs especially. But apart from there is a real strategy to help students get into other courses to do other things at college, to progress into other. You know ... whether it be another English course or something else. [ESOL educator]

Educators and policy-actors associated with this case have shared the view that the learners are extremely motivated towards acquiring 'employment-oriented' vocabulary and developing skills that would enhance their employability. This is recognised and addressed both within classroom teaching and within the college's support services. In the quote below, a tutor provides an example of how she incorporates employability skills into her teaching, both explicitly and implicitly:

Because you're doing targets for people you have to link the employability argument for what they're doing, so someone who is practising for their exam, this is going to help them in job interviews, for example, which they will do. So in that sense it's very explicit. And then the softer implicit kind of approach, which is the pronunciation, you know it's definitely linked. [...] I'll take a very citizenshipbased approach where one of the things that people need to be able to communicate about and those are everyday topics. So it's helping them in those different areas. [ESOL educator]

Acquiring vocabulary and developing English language skills is also strongly interrelated with the socio-cultural dimension, that characterises the delivery of the ESOL programme. The sociocultural element of adult education is associated with equipping the learners with English language skills, to enhance their confidence and facilitate communication within different social environments. The interviews with the learners have also indicated that they feel that through developing their English language skills the course contributes to their confidence and engagement:

I think since I started the course, I can understand better life in [local area]. We are encouraged to read by [our tutors]. I read local newspaper. Most of my classmates are local and we talk about what happens in [local area], and in London, and sometimes in our home countries. We all come from different countries. As we are learning, we can speak more, and can talk about events. Movies. Sometimes. [ESOL Learner]

The findings suggest that the learners perceive their AC through the lens of engagement and participation in a range of context and settings ranging from employment to home and community environments.

\section{Politico-legal dimension: Teaching British values and language as route to citizenship}

The political agenda has strongly emphasised the importance of English language skill as a prerequisite of the integration of migrants and refugees, and specifically for contributing to embracing British values and enhancing civic participation, which relates to the third dimension of AC, that is, politico-legal dimension.

The role of language in enabling immigrants to integrate into society has been traced in subsequent policy developments. Since 2013, there has been an increase in the level of the language 
requirement for naturalisation and settlement, also supplemented by the Life in the United Kingdom (UK) citizenship test (LITUK). It has been strongly promoted that 'Individuals seeking British naturalisation or settlement will be required to hold English language qualifications as well as passing the Life in the UK test (LITUK)', (statement from the then Immigration Minister Mark Harper in 2013). This statement and political agenda placed a higher responsibility on ESOL provision to teach British values and facilitate AC for the learners. Moreover, as a result of events such as the London bombings in 2005, the New Labour government was extremely keen to construct a notion of the British citizen, underpinned by British values. From 2015, all education providers are subject to a duty under the Counter-Terrorism and Security Act 2015, to take measures to prevent extremism and radicalisation ('Prevent' programme) and to promote so-called 'fundamental British values' in all their programmes and activities. These include 'democracy, the rule of law, individual liberty and mutual respect and tolerance for those with different faiths and beliefs' (HM Government, 2015: 5). The requirement that educational organisations promote these values as British values has been controversial from the point of its implementation (Huegler and Kersh, 2021). Both the Educators and policy makers interviewed for the EduMap project, have noted that the overall policy, needs a careful 'translation' into specific approaches in the context of adult education.

I really, really dislike the idea that we have to teach British values. I think it's in itself a racist term and I think that creates vulnerability as well because it creates a distrust between cultures that make up the DNA of our country ... If you take away the identity of where they come from and replace it with British identity then you are further dividing a nation that could be celebrating something that is a fantastic thing. [ESOL educator].

A policy maker similarly makes a point that although it's important to promote the principle of democracy, rule of law, tolerance of others, there is an undergoing pressure to 'demonstrate' that British values are being taught:

We're very conscious of our duty to fulfil our Prevent duty and also to promote British values ... what it does do is give that opportunity to engage with learners and bring about discussions about things like the principles of democracy, rule of law, tolerance of others etc which I would argue are facets of effective citizenship. So we do it but not because we're trying to create good citizens - although hopefully we are - it's partly out of the regime that we're obliged to work within, including inspection which expects all of those things to be demonstrated and present. [UK Policy Maker]

Our findings suggest that the explicit teaching of these principles, does not always work, and may generate further tensions and resistance. Conversely, implicit (rather than explicit focus) way of promoting British values, knowledge about life in the UK, and contextualising this in activities relevant to the learners' situations provide a more meaningful context for integration. One of the educators, reflected on her own strategies to develop the learners' politico-legal competencies, including civic awareness. Introducing aspects of British values provides a context for raising civic and political awareness for learners. However, given that the learners originally come from different countries and cultures, they need to be introduced to various civic and citizenship concepts gradually, taking into account their own cultural differences and personal experiences: 
I talk about their Remembrance Days and the equivalent national sorts of festivals that they have in their countries, but I will try and interpret those for them so they know what's around them in a sense. [ESOL educator]

This approach characterises elements of good practice that takes into account recognising the learners' own cultural heritage and backgrounds, specifically addressing this through highlighting some parallels between values in the UK and the learners' countries of birth. This sort of contextualisation makes the discussion about British values more context-specific and relevant to the learners' personal contexts, thus facilitating their awareness of democracy, tolerance and AC.

\section{Policy learning through embedding strategies into specific adult education contexts: Mentoring programme example}

There has been significant policy attention across Europe and the UK focussing on disadvantaged young people, including those who have experienced care (care leavers). Disadvantage can be manyfold, and often this target group experience multiple disadvantages at any one time. Hence, this is a heterogeneous group of young people with complex needs. Disengagement from learning is a complex phenomenon (The European Commission, 2011). The Commission's growth strategy, Europe 2020, advises member states to develop comprehensive policies to address early school leaving involving 'prevention', 'intervention' and 'compensation' measures. These categories were developed on the basis of a number of good practices across Europe (European Commission, 2013). The Department for Education in the UK aims to improve the aspiration and achievements of disadvantaged young people by policy developments, for example, to support their transition from school to work and engaging them in meaningful education and training post-16. Social inclusion of disadvantaged young people, however, should be addresses holistically (Fahmy, 2008). Fahmy argues that

... tackling youth marginalisation [...] involves a commitment to promoting the material and social welfare of young people as citizens (and not simply as workers) (p. 286)

Although UK wide social policy influences the approaches of the UK's devolved nations, there are noticeable differences between the education and social policies in each nation. Scotland has developed its own policy of lifelong learning through 'Skills for Scotland' papers in 2007 and 2010. These documents focus on the matching of skills with employer needs, simplifying the skills system as well as partnerships between public, private and voluntary organisations in the lifelong learning sector (European Commission, 2015). The 'Statement of Ambition' for adult learning (Education Scotland, 2014) further emphasises the personal development and societal benefits of adult learning.

Care experienced young adults are one group that is considered as highly vulnerable. The case study in Scotland has a focus on care experienced young adults, and mentoring has been implemented as an innovative approach, contributing to policy learning through local innovation and experiences (Raffe and Spours, 2006). Existing research indicates that within this group there is particularly high risk of social exclusion and poor outcomes especially in relation to education, employment, mental health, as well as identity and self-esteem. Care experienced young adults are also disproportionately affected by homelessness and offending, and fundamentally underrepresented in higher education. Hence preventative measures and tailored programmes are necessary to support those young adults who have experienced care in their lives. It is equally important for these young adults to maintain continuity in their education and achieve their full potential. 
Consequently, targeted and holistic programmes may break down barriers of social and economic exclusion of vulnerable young adults and enhance political, social and economic participation.

Given the complexity of needs of the young adults on the programme, the programme has been developed to support social and economic inclusion in a holistic manner. The programme was designed to ensure that young people who experience disadvantage would have the same educational outcomes, career opportunities and life chances as any other young person. This initiative has been started by a non-governmental organisation (NGO), external to the education system. Over time it has developed close links and strong and innovative partnership with the city council to support vulnerable young adults in several locations across Scotland.

Discourse about disadvantaged young adults raises the question; is this a welfare issue or an education issue? Should the agenda of social inclusion of disadvantaged young adults rest with welfare or education? Within the case study it was recognised from the outset that the programme can only be successful if it is about education, and it should be an integral part of the education system rather than an add-on. It supplements and complements the mainstream education process as one school representative explains:

'[The programme is] just an element of that and we need to be making sure [it is] blending into the whole school approach and the whole education approach, [the programme has] got the same objectives and outcomes, and also that [the NGO is] using all of the connections the council has to offer to get the opportunities for the young people.'

The model has evolved over time and proved to have positive impact on young people's education, motivation and destination. According to the NGO, the ultimate aim was to 'give [young people] the tools, the strength, the abilities then to create a better version in the future, and education, job choices, life chances'. This approach supports young adults overcoming challenges set by changing global and national contexts.

The programme is complex and consists of several elements to ensure its effectiveness. These include mentoring, bite sized taster sessions at higher and further education, enterprises and in-built regular communication among all stakeholders (schools, NGO, mentors and employers). For each young person the programme evolves over years. As the Lead reflected 'What we are effectively doing is carefully injecting additionality at the times that it's needed'.

The initial stage focusses on developing relationships, developing trust with the young people and identifying their individual needs, then mentoring is introduced which then followed by taster sessions. Mentoring is the main element within the programme. The positive mentor-mentee relationship enables young people to start to develop their self-confidence their self-belief and their ability to achieve which are critical to being able to play a positive, active role in society, as a senior leadership team member from the NGO explains:

I think first and foremost confidence and self-belief. Yeah because their confidence and self-belief in many cases is rock bottom. And they may be young people and they very often are young people who have had a series of setbacks in their life, who have got difficult circumstances and who are used to not achieving success. And so what they can see from this mentor is that you can still achieve success.

Without the confidence and self-belief, there is a strong possibility that the young people will not feel able to take up the opportunities offered within the programme. Time with the mentor offers young people a platform to discuss their education, career plans but also their hobbies and interests. 
Young people lead the mentoring session and suggest areas for discussion. One of the mentors describes it as

a personal relationship you're developing and you're helping that person. It's the whole of you and you're helping the whole of that person ... it's kind of a brand new relationship which isn't a relative, isn't a teacher, isn't a friend, isn't a counsellor, it's something else, it's like a life coach'

And a policy maker considers it as

... it's purely about relationship first and foremost, active listening ... empathising ... trust. Once that's established then it really is about what is the potential of that young person ... the mentor's role is to help that young person, find, grow and use their talents.

Mentoring was clearly one of the success factors and mentors offered these young adults undivided attention and individualised support. For the mentees, their mentor is often the first person to take an active interest in their future. As one educator comments:

... There's a very powerful message in somebody giving up some of their time for an hour a week, or in some cases it can be more, to say 'you have value as a person and as an individual'. Do you know, that in itself, even the fact that somebody actually cares enough to come, commit, and come back ... And you've got a consistent person that comes in with similar interests to you, they're matched up so that, you know they're tailored up either to a young person's aspirations and their interests, somebody that comes in to act as a role model. But also I think partly it is just somebody keeps coming back every week

Many of young adults involved with the programme come from complex backgrounds, surrounded by adults who drain their self-belief and consistently undermine them, as one young adult recalls, 'oh you won't be able to look after yourself, you won't be able to cope'.

There is also a 'talent taster team' within the NGO that recruit colleges, universities and employers and they set up a host of opportunities for the young people to try. These opportunities include an arts and culture programme, college tasters, university tasters, placements and employment opportunities. Their philosophy is rather than believing that:

... 'these young people are defined by their circumstances' we are trying to say 'well be defined by your talent, not your circumstances', hence it's 'go try'. And actually it's the process of trying that we're really keen on. So if you like it, fabulous, if you don't like it, that's equally as good, because I'm just wanting you to be able to articulate why you don't like it.

The talent tasters are also key to helping develop socio-economic and socio-cultural citizenship as they provide a way for young people to find out more about what type of employment might suit them:

So I think, you know even with all the tasters they get and experiences they leave with a much better CV, better equipped with their personal statements, but they also from a younger age they understand what a job is, what college is, what pathways they can take, what skills they need, what grades they need at school. So they're becoming a bit more rounded in terms of being prepared. 
The programme takes a positive approach, specifically, it focusses and builds on young people's talents, breaks down the stigmatisation of disadvantage of the participant young people. It is 'forward facing ... it's all future facing so it's aspirational, it's positive, it's upbeat, it's all...you know the language is really, really important', as the NGO founder stresses.

The target group in this case study is still attending mainstream secondary schools. In Scotland, the school leaving age is 16 years. However, the aim of the programme is to support young adults stay in post-16 education and equip them with skills, attitude and behaviour that support them in their future lives. It is evident that positive destinations, employment, college and university, have risen for the participants. So did literacy, numeracy and staying on in education rates.

Over time the programme builds up and explicitly supports the long-term development of political, social and economic participation and skills development of disadvantaged young adults. This can be interpreted as AC in the broad sense. The interviewed young people consistently referred to their participation as a positive experience. Four to five young adults per school acted as ambassadors for the programme. This represented new opportunities for them over and above the programme itself. As ambassadors, they were the voice of young people for their school, they represented their peers in their schools and the whole programme, and they were actively encouraged to engage in communicating ideas to further enhance the experience of the next generation in the programme. Ambassadors were also represented the programme at external events and shared their experiences with stakeholders, such as policy makers, employers and potential mentors. This further improved, for example, their communications skills, self-confidence and presentation skills. These are valuable for both as skills development and enhancement of social participation.

There has been clear evidence for economic participation though the positive destinations. Young people have secured university places, further education training and some employment. The interviewed alumni young adults were evidently in contact with their 'old' local communities and engaged in charity work in support of those of similar backgrounds as themselves. There has been plenty of evidence for how the disadvantaged young adults break down barriers and gradually develop as active participants of the society.

\section{Conclusion}

The consideration of policy learning in the area of social inclusion of vulnerable young adults suggests both some common patterns and some diverse practices embedded in specific adult education programmes. The UK-based cases studied have demonstrated both some common objectives and different approaches and challenges, contextualised in the political landscape of post16 education and adult learning in the UK.

The complex interplay between country-specific priorities, global discourses and the European agenda on AC has contributed to some common patterns, such as facilitating social inclusion through the three dimensions of AC: socio-economic, socio-cultural and politico-legal (Kersh et al., 2021). These common patterns highlight the notion of policy learning (Raffe, 2011a) specifically, the influence of globalisation (Crossley, 2008) and the way political and social trends translate into national policies (Biesta, 2006). The framework offered by Raffe and Spours (2007) has provided a helpful approach for exploring the notion of policy learning within this paper. The influence of global, European and national trends and policy developments has been underpinned by policy learning both as experiential learning or learning from past experience, and learning from other countries or global experience, which contributes to understanding one's own system better (Raffe, 2011b) and informing local (e.g. cases specific) solutions and decisions (Burdett and O'Donnell, 2016). Although overall policy directions and policy learning have been influenced and shaped by 
the global discourses and national priorities, translating and implementing these policies into specific adult education settings, as our cases indicate, is highly contextualised, and involves policy learning not only from the national agenda, but also from local innovations and approaches, and local adaptations (Steiner-Khamsi, 2014) in response to the specific needs of vulnerable young adults.

The employability agenda associated with the neo-liberal discourse has provided a very powerful context and rationale for the development of approaches to move young adults into work, enabling them to learn the skills required by the contemporary labour market. However, developing employability is very instrumental and a holistic approach is needed to enhance social inclusion and the development of AC of young adults. The contextualisation of the policy agenda, for particular programmes, has indicated diverse strategies, which take into account the specific contextual features and the needs of relevance to the target groups. Implicit rather than explicit ways of the promotion of policies and agendas on active participatory citizenship were highlighted by both the desk research and through the exploration of the cases studies. The two cases considered in this paper, exemplified diverse approaches to promote the dimensions of AC. The Scottish case has illustrated the ways the mentoring approach has been employed to facilitate inclusion and AC of vulnerable young adults (care leavers). The ESOL case from England, has demonstrated a strong focus on the development of language and communication skills to promote inclusion and life chance of migrants and refugees. The provision of English as a second language, for migrants and refugees has been oriented towards equipping the learners with skills that would help them to integrate into the UK's social and economic life. The consideration of these two cases have supported our overall findings from the EduMap empirical research, undertaken in different crosscultural contexts. The findings have indicated that national policy approaches towards inclusion and promotion of AC have often been driven by political goals and priorities, rather than by the real needs of vulnerable groups. However, contextualising and translating these policies into specific adult education contexts provides affordances for the development of more specific strategies and approaches to address the actual needs of vulnerable young adults. Therefore (see also Kersh et al., 2021), the elements of successful policies and practices in re-engaging vulnerable young people strongly relate to addressing their specific needs and facilitating their inclusion and $\mathrm{AC}$, rather than just focussing on addressing current policy agenda. This involves the implementation of innovative approaches such as contextualising AC dimensions in ways that are relevant to young adults' personal backgrounds and/or professional aims; creating opportunities to exercise AC in all its dimensions and related to young adults' experiences and personal situations and employing flexibility and personalisation strategies rather than 'one size fits all' approach, that is,. ensuring flexible provision that provides personalised approaches in developing educational programmes.

Our overall recommendation for policy and practice is that the importance of addressing the specific needs of vulnerable young adults and facilitating their inclusion and AC needs to be better recognised and taken into account by relevant stakeholders (e.g. course designers and policy makers). The EduMap research has indicated the need to embed adult education and AC in a broader frame that considers social inclusion as a multidimensional process (spanning interpersonal, social, cultural and economic dimensions) that is conducive to stronger, more resilient societies. Supporting the active participation of young adults does not only benefit them, but the entire sociocultural and economic structure, from a larger and better equipped workforce to strengthened democratic structures. This requires securing and ensuring strong and coherent national and local policies, incorporating education, that understand social inclusion as a multidimensional and complex process that needs to be supported by effective diversity and equality policies. In addition, promoting diversity-oriented policies in labour and employment, which consider the workforce 
potential of young people at risk of exclusion as an asset, and treats them equally with others (EduMap Policy Brief 2, 2019).

It is worth noting that the research cases considered in this paper have been undertaken prior to the COVID-19 pandemic. The implications of the COVID-19 crisis have had a further impact on adult education and social inclusion, and the ways young adults improve their life chances. This has been specifically noted for the vulnerable group of young people who were considerably worse hit by the pandemic. The significant challenges of the COVID-19 situation as well as its implications for social inclusion of young adults needs to be taken into account in further research on adult education locally, in Europe and globally.

\section{Declaration of conflicting interests}

The author(s) declared no potential conflicts of interest with respect to the research, authorship, and/or publication of this article.

\section{Funding}

The author(s) disclosed receipt of the following financial support for the research, authorship, and/or publication of this article: This paper draws on findings of the research project Adult Education as a Means to Active Participatory Citizenship (EduMAP). The project was funded by the European Union under the European Union's Horizon 2020 Research and Innovation Programme (H2020-YOUNG-2014-2015/H2020YOUNG-SOCIETY-2015), Grant Agreement number 693388.

\section{References}

Association of Colleges (2021) FE White Paper - AoC's response. Available at: https://www.aoc.co.uk/fewhite-paper-aocs-response (accessed 19 September 2021).

Biesta G (2006) What's the point of lifelong learning if lifelong learning has no point? European Educational Research Journal 5(3-4): 169-180. DOI: 10.2304/eerj.2006.5.3.169

Boeren E and Holford J (2016) Vocationalism varies (a lot): a 12-country multivariate analysis of participation in formal adult learning. Adult Education Quarterly 66(2): 120-42.

Breyer L (2018) Patterns of difference in understandings of equity and social justice in adult education policies: comparing national reports in international contexts by a lexicometric analysis. Studies in the Education of Adults 50(2): 152-166.

Brooks R and Holford J (2009) Citizenship, Learning, Education: Themes and Issues. Citizenship Studies 13(2): 85-103.

Burdett N and O'Donnell S (2016) Lost in translation? The challenges of educational policy borrowing. Educational Research 58(2): 113-120. DOI: 10.1080/00131881.2016.1168678

Casey L (2016) The Casey Review. A review into opportunity and integration. MHCLG. Department for Communities and Local Government. Available at: https:/www.gov.uk/government/uploads/system/ uploads/attachment_data/file/575973/The_Casey_Review_Report.pdf (accessed 19 September 2021).

Commission of the European Communities (2000). A memorandum on lifelong learning. Available at: https:// uil.unesco.org/i/doc/lifelong-learning/policies/european-communities-a-memorandum-on-lifelonglearning.pdf (accessed 19 September 2021).

Commission of the European Communities (2001) Making a European Area of Lifelong Learning. Communication from the Commission. Available at: https://eur-lex.europa.eu/LexUriServ/LexUriServ.do? uri=COM:2001:0678:FIN:EN:PDF (accessed 19 September 2021). 
Commission of the European Communities (2006) Adult Learning: It is Never Too Late to Learn. Communication from the Commission. Available at: https://eur-lex.europa.eu/legal-content/EN/TXT/HTML/? uri=CELEX:52006DC0614\& from=EN (accessed 19 September 2021).

Commission of the European Communities (2007) Action Plan on Adult Learning: It is Always a Good Time to Learn. Communication from the Commission. Available at: https://eur-lex.europa.eu/legal-content/EN/ TXT/?uri=celex\%3A52007DC0558 (accessed 19 September 2021).

Council of the European Union (2011) Council Resolution on a renewed European agenda for adult learning. Available at: http://www.basicskills.eu/wp-content/uploads/2013/08/Council-Resolution.pdf (accessed 19 September 2021).

Council of the European Union (2016) Council Recommendation of 19 December 2016 on Upskilling Pathways: New Opportunities for Adults. Available at: https:/eur-lex.europa.eu/legal-content/EN/TXT/ PDF/?uri=CELEX:32016H1224(01)\&from=EN (accessed 19 September 2021).

Crossley M (2008) Postscript: locating narrative research in comparative education. Compare 38(3): 363-365. DOI: $10.1080 / 03057920802083563$

Crossley M (2019) Policy transfer, sustainable development and the contexts of education. Compare: A Journal of Comparative and International Education 49(2): 175-191. DOI: 10.1080/03057925.2018.1558811

Department for Education (2021) Skills for Jobs: Lifelong Learning for Opportunity and Growth. The White Paper, presented to Parliament by the Secretary of State for Education by Command of Her Majesty. Available at: https://assets.publishing.service.gov.uk/government/uploads/system/uploads/attachment_data/ file/957856/Skills_for_jobs_lifelong_learning_for_opportunity_and_growth_web_version_.pdf (accessed 15 November 2021).

Education Scotland (2014) Adult Learning in Scotland- Statement of Ambition. Available at: https://dera.ioe.ac. uk/24356/2/AdultLearningStatementofAmbition_tcm4-826940_Redacted.pdf (accessed 19 September 2021).

EduMap Policy Brief 2 (2019) Good Practices of Adult Education for Young Adults at Risk of Social Exclusion: Towards Active Participatory Citizenship. Available at: https://projects.tuni.fi/edumap/policycorner/ edumap-policy-brief-updates-published (accessed 19 September 2021).

European Commission (2013) Commission Recommendation of 20 February 2013 Investing in children: breaking the cycle of disadvantage. Available at: http://eur-lex.europa.eu/legal-content/EN/ ALL/?uri= CELEX:32013H0112 (accessed 19 September 2021).

European Commission (2015) Adult Education and Training in Europe: Programmes to Raise Achievement in Basic Skills. Eurydice Report. Luxembourg: Publications Office of the European Union. Available at: http://publications.europa.eu/resource/cellar/e71816d0-ab24-4be4-ba2f-b825f6cbe5eb.0001.01/DOC_ 1 (accessed 19 September 2021).

European Commission (2016) A new skills agenda for Europe: Working Together to Strengthen Human Capital, Employability and Competitiveness. Strasbourg. Available at: https://community.oecd.org/docs/ DOC-131502 (accessed 19 September 2021).

Evans K and Niemeyer B (eds) (2004) Reconnection Countering Social Exclusion through Situated Learning. Springer.

Evans K (2009) Learning, Work and Social Responsibility. Dordrecht: Springer.

Fahmy E (2008) Tackling youth exclusion in the UK: Challenges for current policy and practice. Social Work \& Society 6(2): 278-288.

Faure E, Herrera F and Kaddoura A (1972) Learning to Be: The world of education today and tomorrow. Paris: UNESCO. Available at: https://unesdoc.unesco.org/ark:/48223/pf0000001801 (accessed 19 September 2021).

Forestier K, Adamson B, Han C, et al. (2016) Referencing and borrowing from other systems: the Hong Kong education reforms. Educational Research 58(2): 149-165. DOI: 10.1080/00131881.2016.1165411 
Field J and Schemmann M (2017) International organisations and the construction of the learning active citizen: an analysis of adult learning policy documents from a Durkheimian perspective. International Journal of Lifelong Education 36(1-2): 164-179.

Foster D and Bolton P (2018) Adult ESOL in England. Briefing Paper Number 7905. Available at: https:// commonslibrary.parliament.uk/research-briefings/cbp-7905 (accessed 19 September 2021).

GRALE III (2016) Global Report on Adult Learning and Education 2016. UNESCO Institute for Lifelong Learning. Available at: http://uil.unesco.org/system/files/grale-3.pdf (accessed 19 September 2021).

GRALE IV (2019) Global Report on Adult Learning and Education 2016. UNESCO Institute for Lifelong Learning. Available at: https://unesdoc.unesco.org/ark:/48223/pf0000372274 (accessed 19 September 2021).

Henn M, Weinstein M and Forrest S (2005) Uninterested Youth? Young People's Attitudes towards Party Politics in Britain. Political Studies 53(3): 556-578.

HM Government (2013) Care Leaver Strategy A cross-departmental strategy for young people leaving care. Available at: https://assets.publishing.service.gov.uk/government/uploads/system/uploads/attachment_ data/file/266484/Care_Leaver_Strategy.pdf (accessed 19 September 2021).

HM Government (2015) Prevent Duty Guidance for further education institutions in England and Wales. Available at: https://assets.publishing.service.gov.uk/government/uploads/system/uploads/attachment_ data/file/445915/Prevent_Duty_Guidance_For_Further_Education_England_Wales_-Interactive.pdf (accessed 19 September 2021).

HM Government (2018) Integrated Communities Strategy Green Paper Building stronger, more united communities. Available at: https://assets.publishing.service.gov.uk/government/uploads/system/uploads/ attachment_data/file/696993/Integrated_Communities_Strategy.pdf (accessed 19 September 2021).

Holford J, Riddell S and Weedon E (2008) Patterns of Lifelong Learning: Policies and Practice in an Expanding Europe. Vienna: Lit Verlag.

Holford J and Welikala T (2013) 'Renaissance' without enlightenment: New Labour's 'Learning Age' 19972010. In: Saar E, Ure OB and Holford J (eds) Building a European Lifelong Learning Society: National Patterns and Challenges. Cheltenham: Edward Elgar, 140-164.

Hopkins N (2014) Citizenship and Democracy in Further and Adult Education. London: Springer

Huegler N and Kersh N (2021) Social inclusion, participation and citizenship in contexts of neoliberalism: examples of adult education policy and practice with Young People in the UK, The Netherlands and Ireland. In: Kersh N, Toiviainen H, Pitkäne P, et al. (eds) Young Adults and Active Citizenship. Springer International Publishing, 57-78.

James N and Thériault V (2020) Adult education in times of the COVID-19 pandemic: inequalities, changes, and resilience. Studies in the Education of Adults 52(2): 129-133. DOI: 10.1080/02660830.2020.1811474

Jarvis P (2012) Adult Learning in the Social Context. London: Routledge.

Kersh N and Huegler N (2018) Facilitating lifelong learning through vocational education and training: promoting inclusion and opportunities for young people in the UK. In: McGrath S, Mulder M, Papier J, et al. (eds.) Handbook of Vocational Education and Training: Developments in the Changing World of Work. Springer, 111-117

Kersh N, Toiviainen H, Pitkänen P, et al. (eds) (2021) Young Adults and Active Citizenship Towards Social Inclusion through Adult Education. Springer. Available at: https://ink.springer.com/book/10.1007/978-3030-65002-5\#about (accessed 19 September 2021).

Lisbon European Council (2000) Presidency Conclusions. Available at: http://www.consilium.europa.eu/ ueDocs/cms_Data/docs/pressData/en/ec/00100-r1.en0.htm (accessed 19 September 2021).

Milana M and Holford J (eds) (2014) Adult Education Policy and the European Union: Theoretical and Methodological Perspectives. Leiden, Boston: Brill: Sense. 
Phillips D and Ochs K (2003) Processes of policy borrowing in education: some explanatory and analytical devices. Comparative Education 39(4): 451-461.

Raffe D (2011a) Cross-national differences in education-work transitions. In London M (ed) The Oxford Handbook of Lifelong Learning. New York: Oxford University Press, 312-328

Raffe D (2011b) Policy borrowing or policy learning? How (not) to improve education systems. Brief 57. Available at: http://www.ces.ed.ac.uk/PDF\%20Files/Brief057.pdf (accessed 19 September 2021).

Raffe D and Spours K (eds) (2007) Policy-making and policy learning in 14-19 education. London: University of London. Institute of Education.

Report of the Centenary Commission (2019) A Permanent National Necessity... Adult Education and Lifelong Learning for 21st Century Britain. Available at: https://www.centenarycommission.org/\#download (accessed 19 September 2021).

Saar E, Ure OB and Holford J (eds) (2013) Building a European Lifelong Learning Society: National Patterns and Challenges. Cheltenham: Edward Elgar

Schmidt-Behlau B (2019) Targeted Research on Best Practices among Vulnerable Groups. Deliverable 3.1 EduMAP Research Project. Available at: https://projects.tuni.fi/uploads/2019/12/ab48fbad-edumap deliverable_3.1.pdf (accessed 19 September 2021).

Steiner-Khamsi G (2014) Cross-national policy borrowing: understanding reception and translation. Asia Pacific Journal of Education 34(2): 153-167. DOI: 10.1080/02188791.2013.875649

UK Government (2000) Children Leaving Care Act 2000. Avaialbe at: https://www.legislation.gov.uk/ukpga/ 2000/35/contents (accessed 19 September 2021).

UK Government (2008) Children and Young Person Act 2008. Avaialbe at: https://bills.parliament.uk/bills/194 (accessed 19 September 2021).

Vromen A (2003) 'People Try to Put Us Down': Participatory Citizenship of 'Generation X'. Australian Journal of Political Science 38(1): 79-99. DOI: 10.1080/1036114032000056260

Volles N (2014) Lifelong learning in the EU: changing conceptualisations, actors, and policies. Studies in Higher Education 41(2): 343-363. DOI: 10.1080/03075079.2014.927852

Waller R, Hodge S, Holford J, et al. (2020) Lifelong education, social inequality and the COVID-19 health pandemic. International Journal of Lifelong Education 39(3): 243-246. DOI: 10.1080/02601370.2020. 1790267

Wolf A (2011) Review of vocational education - the Wolf Report. Available at: https://assets.publishing. service.gov.uk/government/uploads/system/uploads/attachment_data/file/180504/DFE-00031-2011.pdf (accessed 19 September 2021). 